\title{
Pengaruh Kepribadian Guru Pendidikan Agama Islam Terhadap Motivasi Siswa Berjilbab Kelas VI Di SD Negeri 18 Sungaiselan Kabupaten Bangka Tengah
}

\author{
Susilawati ${ }^{1}$, Janawi², Anna Musyarofah ${ }^{3}$ \\ 1IAIN Syaikh Abdurrahman Siddik \\ 2IAIN Syaikh Abdurrahman Siddik \\ 3IAIN Syaikh Abdurrahman Siddik
}

\begin{tabular}{l}
\hline \hline Info Artikel : \\
\hline Diterima 12 Maret, 202x \\
Direvisi20 Agustus, 202x \\
Dipublikasikan 31 Mei 2020
\end{tabular}

\section{Kata Kunci:}

Pengaruh Kepribadian guru, Motivasi Berjilbab,

Pendidikan Agama Islam

\section{Keywords:}

The influence of the teacher's personality,

Headscarves Motivation,

Islamic education

\begin{abstract}
ABSTRAK
Penelitian ini bertujuan untuk mengungkapkan pengaruh antara kedua variabel tersebut. Penelitian ini menggunakan jenis penelitian kuantitatif deskriptif dengan menggunakan rumus regresi linier sederhana. Adapun teknik pengumpulan data menggunakan angket tertutup, dokumentasi. Data yang telah dikumpulkan selanjutnya akan dianalisis dengan menggunakan bantuan program SPSS 22.0. Hasil yang diperoleh dari penelitian pengaruh kepribadian guru pendidikan agama Islam terhadap motivasi siswa berjilbab kelas VI di SD Negeri 18 Sungaiselan Kabupaten Bangka Tengah, sesuai dengan hasil pengujian hipotesis menunjukkan bahwa jika nilai $\mathrm{T}_{\text {hitung }}>\mathrm{T}_{\text {tabel }}$ pada taraf signifikasi 5\% (0,05) dengan angka 3 angka 2,789>1,739 berarti Ha diterima dan Ho ditolak. Sedangkan besar pengaruh antara variabel $\mathrm{X}$ terhadap $\mathrm{Y}$ sebesar 31,4 \% dengan melihat tabel $\mathrm{R}$ Square (koefisien determinasi) $\mathrm{R}^{2}=0,314$ X $100=31,4 \%$ dan sisanya 68,6 \% dipengaruhi faktor lain. Dengan demikian disimpulakan bahwa terdapat pengaruh yang signifikan antara kepribadian guru pendidikan agama Islam terhadap motivasi siswa berjilbab. Adapun bentuk persamaan regresi sesuai dengan yang diperoleh pada tabel Coefficients ${ }^{a}$ diperoleh nilai konstanta 13,196 dan niali koefisien b1 (kepribadian guru PAI) sebesar 0,579. Maka bentuk persamaan regresi linier sederhana $\hat{Y}=13,196+0,579 X$.
\end{abstract}

\section{ABSTRACT}

This study aims to reveal the effect between these two variables. This research uses descriptive quantitative research by using a simple linear regression formula. The data collection technique uses a closed questionnaire, documentation. The data collected will then be analyzed using SPSS 22.0 program assistance. The results obtained from the study of the influence of the personality of Islamic religious education teachers on the motivation of veiled class VI students at SD Negeri 18 Sungaiselan, Central Bangka Regency, in accordance with the results of hypothesis testing show that if the value of Tcount> Ttable at the significance level of 5\% (0.05) with numbers 3 numbers 2,789> 1,739 means that Ha is accepted and Ho is rejected. While the influence of the variable $X$ to $Y$ was $31.4 \%$ by looking at the $R$ Square table (coefficient of determination) $R 2=0.314 \times 100=31.4 \%$ and the remaining $68.6 \%$ was influenced by other factors. Thus it is concluded that there is a significant influence between the personality of Islamic religious education teachers on the motivation of veiled students. The form of the regression equation in accordance with that obtained in the Coefficientsa table obtained a constant value of 13.196 and the coefficient value b1 (personality of the PAI teacher) was 0.579. Then the simple linear regression equation form $\hat{Y}=13,196+$ $0.579 X$.

\section{Koresponden:(9 pt)}

Susilawati

Email: susisusilawati@gmail.com 


\section{PENDAHULUAN}

Kepribadian adalah keseluruhan dari individu yang terdiri dari unsur psikis dan fisik. Dalam makna yang demikian, maka seluruh sikap dan perbuatan seseorang merupakan suatu gambaran dari kepribadian orang itu. Kepribadian sesungguhnya bersifat abstrak yang susah untuk dilihat atau diketahui secara nyata. Namun yang dapat diketahui adalah penampilan, atau bekasnya dalam segi dan aspek kehidupan. Misalnya, tindakan, ucapan, cara bergaul, berpakaian, dan dalam menghadapi baik persoalan atau masalah ringan maupun berat. ${ }^{1}$

Guru adalah panutan bagi peserta didik dan menjadi seorang guru haruslah memiliki kepribadian yang positif yang dapat dijadikan sumber inspirasi bagi peserta didik. Seperti yang diungkapkan oleh Ki Hajar Dewantara dalam sistem pendidikan yang diinginkan yaitu guru harus "ing ngarsa sung tuladha, ing madya mangun karsa, tut wuru handayani" yang artinya bahwa guru harus menjadi contoh dan teladan yang baik, yang membangkitkan motivasi belajar siswa serta mendorong dan memberikan dukungan dari belakang. ${ }^{2}$

Guru pendidikan agama Islam merupakan salah satu guru mata pelajaran di sekolah dasar yang mempunyai peranan yang sangat penting dalam pembentukan kepribadian peserta didik yang bermoral dan berakhlak mulia serta berkepribadian Islami. ${ }^{3}$ Oleh sebab itu seorang guru dituntut untuk senantiasa mengembangkan potensinya dalam menguasai berbagai kompetensi yang semakin berkembang saat ini. Selain dari pengalaman yang menjadi titik eratnya kepribadian guru dengan motivasi siswa. Guru juga diharapkan menjadi sosok teladan bagi siswa khususnya dari segi menggunakan jilbab, karena yang mana kita ketahui jilbab adalah sesuatu yang wajib digunakan oleh seorang muslimah. Islam juga mewajibkan para wanita muslimah untuk menutup auratnya menggunakan jilbab.

Penggunaan jilbab di lingkungan sekolah bukan hal yang aneh lagi, contohnya di SD Negeri 18 Sungaiselan, walaupun tidak diwajibkan menggunakan jilbab ke sekolah tapi siswa tetap menggunakan jilbab. Menurut Bella siswa kelas VI SD Negeri 18 Sungaiselan kebanyakan siswa perempuan menggunakan jilbab di sekolah, khususnya kelas VI yang siswa perempuannya berjumlah 19 orang semuanya menggunakan jilbab. ${ }^{4}$ Dari wawancara siswa ini, salah satu motivasi mereka menggunakan jilbab adalah melihat guru-guru dan teman-teman mereka yang berjilbab. Alasan lainnya mereka berjilbab karena diwajibkan berjilbab pada hari jum'at maka dari situlah timbul rasa senang menggunakan jilbab setiap hari.

SD Negeri 18 Sungaiselan merupakan salah satu SD umum berstatus Negeri di Kabupaten Bangka Tengah yang kebanyakan siswanya yang muslim berjilbab. Menurut guru pendidikan agama Islam, penggunaan jilbab di sekolah tersebut sudah berlangsung sejak tahun 2016 dan merupakan perjuangan panjang, keras dan penuh tantangan untuk mewujudkan sekolah umum yang siswanya berjilbab. Sebelumnya sangat sedikit siswa yang berjilbab termasuk guru dan pegawainya. Namun pada tahun 2018 setelah dilihat banyaknya siswa, guru, dan pegawai yang sudah menggunakan jilbab baik di sekolah maupun di rumah. ${ }^{5}$

Keberhasilan SD Negeri 18 Sungaiselan dalam menerapkan pemakaian berjilbab bagi para siswanya tidak lepas dari peran penting pendidikan agama Islam di sekolah tersebut. Melalui pendidikan agama Islam baik melalui proses pembelajaran di kelas, kegiatan ekstrakurikuler, pengajian-pengajian, diskusi agama Islam, kegiatan rohani Islam, pendekatan personal dan pendekatan-pendekatan keagamaan lainnnya dapat menumbuhkan motivasi dan kesadaran berjilbab kepada para siswa. Hasilnya bahwa seluruh siswa kelas VI yang berjumlah 19 orang memilih menggunakan jilbab meskipun tidak ada aturan yang mengharuskan para siswa untuk berjilbab kecuali pada hari jum'at. ${ }^{6}$ Memang diakui masih ada siswa yang tidak berjilbab ketika di sekolah, namun itu sudah merupakan kemajuan yang besar dimana para siswa memiliki motivasi atau kemauan yang tinggi untuk berjilbab.

Berdasarkan latar belakang masalah tesebut, agar penelitian ini tidak meluas jadi peneliti menetapkan batasan. Oleh karena itu, penelitian ini dikhususkan kepada siswa yang berjilbab kelas VI saja. Setelah itu, hasil penelitian akan diuraikan dalam bentuk skripsi dengan judul "Pengaruh Kepribadian Guru Pendidikan Agama Islam Terhadap Motivasi Siswa Berjilbab Kelas VI di SD Negeri 18 Sungaiselan Kabupaten Bangka Tengah.

Tinjauan Pustaka

Kepribadian

\footnotetext{
${ }^{1}$ Ngainun Naim, Menjadi Guru Ispiratif, (2009):111.

2 Imas Kurniasih \& Berlin Sani, Sukses Uji Kompetensi Guru (UKG), (2015):49.

3 Ramayulis, Ilmu Pendidikan Islam, (2008): 31.

${ }^{4}$ Bella, Siswa kelas V , wawancara, Desa Romadhon, 1 Mei 2018.

${ }^{5}$ Haidir, Guru Pendidikan Agama Islam, wawancara, Desa Romadhon, 5 Mei 2018.

${ }^{6}$ Jumiati, Guru Matematika, wawancara, Desa Romadhon, 4 Mei 2018.
} 
Menurut Zakiah Darajat, dikutip oleh Syaiful Bahri Djamarah mengatakan bahwa "kepribadian yang sesungguhnya adalah abstrak (ma'nawi), sukar dilihat atau diketahui secara nyata, yang bisa diketahui adalah penampilan atau bekasnya dalam segala segi dan aspek kehidupan". ${ }^{7}$ Sedangkan kepribadian guru adalah suatu hal yang sangat menentukan tinggi rendahnya kewibawaan seorang guru dalam pandangan peserta didik dan masyarakat. Dengan kata lain, baik tidaknya citra seorang guru ditentukan oleh kepribadiannya.

Motivasi

Menurut M. Utsman Najati, motivasi adalah kekuatan penggerak yang membangkitkan aktivitas pada makhluk hidup dan menimbulkan tingkah laku serta mengarahkannya menuju tujuan tertentu. Motivasi memiliki tiga komponen pokok, yang menggerakkan, mengarahkan dan menopang. ${ }^{8}$

\section{METODE}

Penelitian ini merupakan jenis penelitian kuantitatif. Metode kuantitatif adalah salah satu metode penelitian yang berupa angka-angka dan analisis menggunakan statistik. ${ }^{9}$ Waktu pelakasanaannya dibagi menjadi dua tahap yaitu pertama tahap perencanaan dilaksanakan pada 1 sampai dengan 5 Mei 2018 tahap observasi ke sekolah dan wawancara. Di lanjutkan lagi dari Juni- Oktober pembuatan borang dan seminar proposal. Kedua, tahap pelaksanaan pengumpulan data dilaksanakan pada bulan Februari - Juni 2019, dan pada bulan Juli penelitian sudah selesai dilaksanakan. Lokasi Penelitian ini bertempat di SD Negeri 18 Sungaiselan, Kabupaten Bangka Tengah.

Variabel Independent (bebas) dan variabel dependent (terikat) pada penelitian ini antara lain: Kepribadian Guru Pendidikan Agama Islam (X) sebagai variabel bebas, Motivasi Siswa Berjilbab (Y) sebagai variabel terikat.

Pengumpulan data yang digunakan pada penelitian ini menggunakan angket dan dokumentasi. Populasi dalam penelitian ini adalah kelas VI SD Negeri 18 Sungaiselan yang berjilbab dengan jumlah 19 siswa. Sementara itu untuk sampel yang digunakan adalah seluruh populasi yang berjumlah 19 orang. Sebelumnya penelitian ini dilakukan uji coba dulu dengan uji validitas. Berdasarkan hasil uji coba validitas terhadap 19 responden, diperoleh hasil yaitu untuk angket kepribadian guru PAI (X) yang berjumlah 17 item peryataan, terdapat 15 item yang valid, sedangkan 2 item pernyataan tidak valid karena rhitung kurang dari $r_{\text {tabel }}(0,482)$. Kemudian untuk angket motivasi siswa berjilbab (Y) berjumlah 14

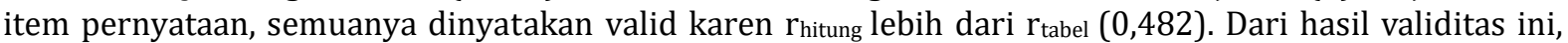
untuk item-item yang tidak valid akan dihilangkan dalam penelitian aslinya.

Setelah itu yang peneliti lakukan adalah uji coba dengan reliabilitas. Berdasarkan hasil penelitian hasil hitungan tingkat reliabilitas yang dihitung dengan rumus Cronbach Alpha dan dibantu dengan program SPSS 22.0. Diperoleh hasil hitungan reliabilitas 17 pernyataan variabel kepribadian guru pendidikan agama Islam (X) sebesar 0,937 dan 14 pernyataan variabel motivasi siswa berjilbab (Y) adalah 0,967. Oleh karena itu nilai alpha $>0,60$. Maka dapat disimpulkan bahwa kedua angket tersebut dinyatakan reliabel dan dapat digunakan sebagai dasar untuk pengambilan keputusan dalam penelitian. Adapun teknik analisis data yang digunakan dalam penelitian ini sebagai berikut :

1. Statistik Deskriptif

Statistik deskriptif adalah statistik yang digunakan untuk menganalisis data dengan cara mendeskripsikan atau menggambarkan data yang telah terkumpul sebagaimana adanya tanpa bermaksud membuat kesimpulan yang berlaku untuk umum atau generalisasi. ${ }^{10}$ Analisis ini juga digunakan untuk melihat skor rata-rata, simpangan baku, median modus, skor minimum, skor maksimum dan dilengkapi dengan histogram.

2. Uji Persyaratan Analisis

Uji Normalitas dilakukan untuk apakah data dari dua variabel penelitian yang diperoleh berasal dari data yang berdistribusi secara normal atau tidak. Uji normalitas data dapat dilakukan dengan berbagai macam cara, tapi pada kesempatan ini digunakan Chi-Kuadrat. Data yang dinyatakan normal apabila signifikansi lebih besar dari 0,05.11 Adapun untuk uji normalitas antar data responden variabel Kepribadian Guru Pendidikan Agama Islam (X) dan Motivasi Siswa Berjilbab (Y) menggunakan bantuan SPSS versi 22.0.

Berdasarkan uji normalitas dapat dilihat pada kolom output Kolmogrov- Smirnova dapat diketahui nilai signifikasi untuk variabel pengaruh kepribadian guru pendidikan agama Islam sebesar ,200.

\footnotetext{
${ }^{7}$ Syaiful Bahri Djamarah, Guru dan Anak Didik dalam Interaksi Edukatif, (2005):39-40.

${ }^{8}$ Nurussakinah Daulay, Pengantar Psikologi dan Pandangan Al-Qur'an tentang Psikologi, (2014):155.

${ }^{9}$ Sugiyono, Metode Penelitian Kuantitatif Kualitatif dan R\&D, (Bandung: Alfabeta, 2014). hlm.7

${ }^{10}$ Kasmadi \& Nia Siti Sunariah, Panduan Modern Penelitian Kuantitatif, (2013):147.

11 Ibid..., hlm. 116
} 
Sedangkan untuk motivasi siswa berjilbab sebesar ,175. Karena signifikasi untuk kedua variabel lebih besar dari 0,05 maka dapat disimpulkan bahwa kedua variabel berdistribusi Normal.

a. Uji Liniearitas

Uji ini bertujuan untuk mengetahui apakah dua variabel mempunyai hubungan yang linier atau tidak. ${ }^{12}$ Pada penelitian ini untuk uji linieritas penulis menggunakan SPSS versi 22.0 dengan menggunakan Test For Linearity pada taraf signifikansi 0,05. Dua variabel dikatakan mempunyai hubungan yang linier apabila signifikansi (liniearity) kurang dari 0,05.13

Dari output ANOVA Table bahwa Linearity sebesar 0, 022. Karena signifikansinya kurang dari 0,05 maka dapat disimpulkan bahwa antara variabel Kepribadian guru Pendidikan agama islam (X) dan motivasi siswa berjilbab (Y) terdapat hubungan yang Linear.

b. Heterokedastistitas

Heteroskedastisitas adalah varian variabel dalam model tersebut tidak konstan atau harus tidak ada. Metode pengambilan keputusan pada uji heteroskedastisitas dengan melihat scatterplot yaitu jika titik-titik menyebar dengan pola yang tidak jelas di atas dan di bawah angka 0 pada sumbu Y maka dapat disimpulkan bahwa tidak terjadi masalah heteroskedastisitas pada morel regresi. ${ }^{14}$ Hasilnya dapat dikemukakan dari hasil output SPSS versi 22.0 sebagai berikut:

\section{Gambar Uji Heteroskedastisitas}

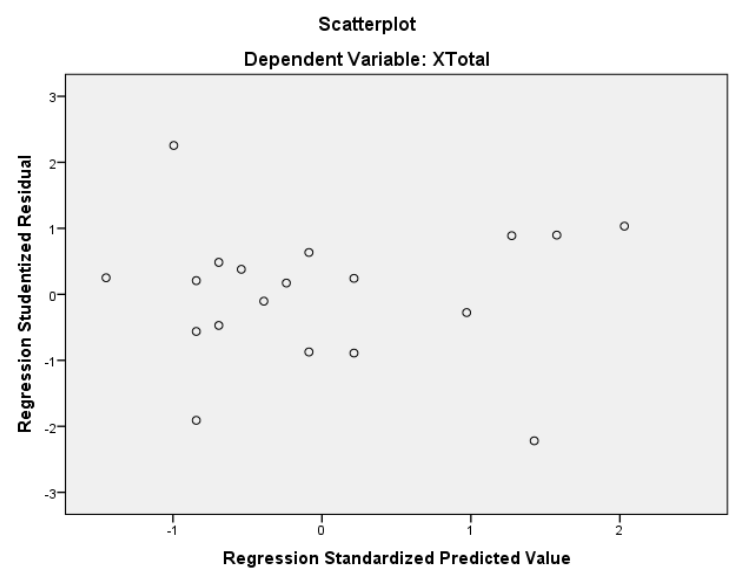

Berdasarkan gambar tersebut memperlihatkan bahwa data terpencar disekitar angka 0 (0 pada sumbu Y), dan tidak membentuk suatu pola atau trend garis-garis tertentu. Dengan demikian, data tersebut dapat disimpulkan bahwa tidak terjadi masalah heteroskedastisitas dalam model regresi.Selanjutnya dalam pengujian hipotesis ini menggunakan taksiran hipotesis nol. Hipotesis diartikan sebagai jawaban sementara terhadap rumusan masalah penelitian. Kebenaran dari hipotesis ini harus dibuktikan melalui data yang terkumpul. Hipotesis tersebut adalah untuk hipotesis penelitian. Sedangkan secara statistik hipotesis diartikan sebagai pernyataan mengenai keadaan populasi (parameter) yang akan diuji kebenarannya berdasarkan data yang diperoleh dari sampel penelitian (statistik). Jadi maksudnya adalah taksiran keadaan populasi melalui data sampel. Oleh karena itu dalam statistik yang diuji adalah hipotesis nol. ${ }^{15}$

Dalam penelitian ini, menggunakan teknik analisis uji Regresi Linier Sederhana yang bertujuan untuk meramalkan dan memperediksi variabel terikat (Y) apabila variabel bebas diketahui (X). ${ }^{16}$ Perhitungan linearitas regresi sederhana menggunakan persamaan:

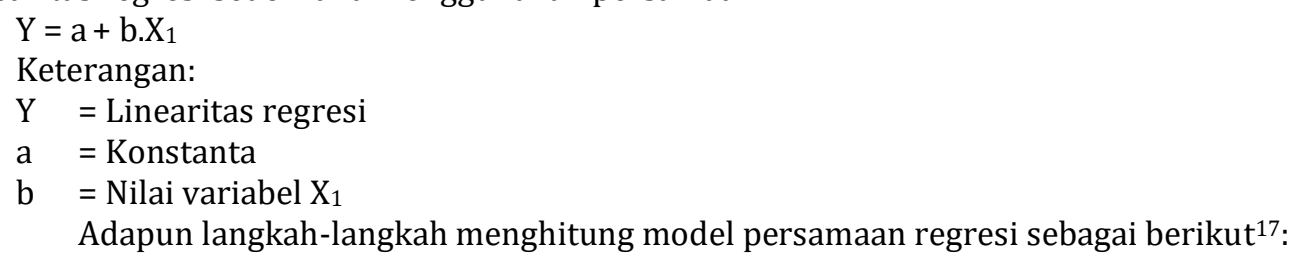

\footnotetext{
12 Kasmadi \& Nia Siti Sunariah, Panduan Modern..., hlm. 120.

13 Ibid., hlm. 121.

14 Wiratna Sujarweni, Kupas Tuntas Penelitian Akutansi dengan SPSS, (2016):231-232.

15 Sugiyono, Metode Penelitian Pendidikan, (Pendekatan Kuantitatif, Kualitatif dan R\&D), (2015): 159-160.

16 Riduwan, Belajar Mudah Penelitian untuk Guru-Karyawan dan Peneliti Pemula, (2012):148.

17 Supardi, Statistik Penelitian Pendidikan (2017):240.
} 
$\mathrm{b}=\frac{\sum X Y}{\sum x^{2}}$

$=\frac{n \sum X Y-\left(\sum x\right)\left(\sum Y\right)}{n \sum X^{2}-\left(\sum x\right)^{2}}$

$\mathrm{a}=\overline{\mathrm{Y}}-\mathrm{bX}$

$=\frac{\left(\sum x^{2}\right)\left(\sum x\right)-\left(\sum x\right)\left(\sum x Y\right)}{n \sum x^{2}-\left(\sum x\right)^{2}}$

c. Autokorelasi

Autokorelasi adalah korelasi yang terjadi antar observasi dalam satu variabel. Tujuan uji ini untuk menguji apakah dalam model regresi linier ada korelasi antara kesalahan pengganggu pada periode $t$ dengan kesalahan pada periode $t 1$ (sebelumnya). Model regresi yang baik adalah regresi yang bebas dari autokorelasi atau tidak terjadi autokorelasi. ${ }^{18}$

Dasar pengambilan keputusan uji autokorelasi biasanya sering digunakan adalah dengan uji DurbinWatson (uji DW) dengan ketentuan sebagai berikut:

1) Nilai DW lebih tinggi dari batas atas (Upper Bound) maka model tersebut mengandung autokorelasi negatif: $0<$ DW statistik $<\mathrm{dL}$.

2) Nilai DW lebih rendah dari batas bawah (lower Bound) maka model tersebut mengandung autokorelasi positif: 4 - $\mathrm{dL}<\mathrm{DW}$ statistik $<4$.

3) Apabila nilai DW statistik berada diantara batas bawah (Lower Bound) dan batas atas (Upper Bound) maka model tersebut berada dalam daerah ragu-ragu: dL d" DW statistik d" dU dan 4-dU d" DW statistik d"4-dL

4) Suatu model dikatakan bebas masalah otokorelasi positif maupun negatif jika DW statistik terletak diantara: dU < DW statistik < 4-dL. ${ }^{19}$

Dari hasil perhitungan dengan SPSS versi 22.0, pengaruh variabel independent (X) terhadap variabel dependent (Y) dinilai dari nilai statistik Durbin Watson sebesar 2,627 sesuai dengan kriteria bahwa signifikansi 0,05 dengan nilai $\mathrm{n}=19$ dan $\mathrm{k}=2$. Hasilnya didapat $\mathrm{dL}=1,0743$ dan $\mathrm{dU}=1,5355$. Jadi dapat dihitung nilai 4- $\mathrm{dU}=2,4645$ dan $4-\mathrm{dL}=2,9257$. Jadi dapat disimpulkan bahwa $\mathrm{dU}<\mathrm{DW}$ statistik < 4- dL $(1,5355<2,627<2,9257)$ dinyakan tidak ada masalah autokorelasi pada model regresi.

\section{HASIL DAN PEMBAHASAN}

A. Hasil Penelitian

Deskripsi Kepribadian Guru Pendidikan Agama Islam

Berdasarkan rumusan masalah yang telah diajukan pada bab sebelumnya, maka tahap awal yang dilakukan adalah memberikan item angket (intrumen penelitian) variabel dependen dan independen yang telah di uji validitas reliabilitasnya kepada siswa kelas VI SD Negeri 18 Sungaiselan Kabupaten Bangka Tengah. Maka langkah pertama yang dilakukan adalah dengan memberikan item angket. Sebelum digunakan pada subjek penelitian yang sebenarnya, alat ukur yang digunakan dalam data penelitian ini diuji coba terlebih dahulu. Tujuan dari uji coba adalah untuk menyeleksi item-item manakah yang valid dan reliabel agar dapat digunakan dalam penelitian. Data yang telah diperoleh saat diuji coba kemudian dianalisis menggunakan bantuan program SPSS (Statistical Product and Service Solution) versi 22.0.

Adapun dalam penelitian ini item yang disediakan untuk mengukur pengaruh kepribadian guru pendidikan agama Islam dari berjumlah 17 item pernyataan, terdapat 15 item pernyataan yang valid.

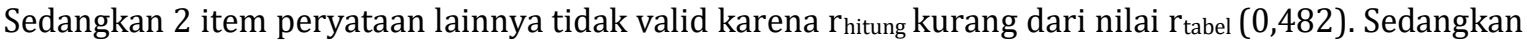
untuk mengukur tingkat kepercayaan atau reliabilitas instrumen angket menggunakan rumus Cronbach Alpha, reliabilitas dari data hasil instrumen peneliti dinyatakan reliabel atau konsisten, karena perhitungannya lebih tinggi dari 0,60 (alpa>0,60).

Berdasarkan hasil deskriptif data responden dari skor hasil perhitungan angket variabel kepribadian guru pendidikan agama Islam dengan bantuan SPSS versi 22.0 diperoleh hasil dari 19 responden, mulai dari rata-rata (mean) 74,95, titik tengah (Median) 75,00, nilai yang sering muncul (Mode) 75, simpangan baku (Standar deviasi) 6,399, tingkat penyebaran data (Variance) 40,942, rentangan (Range) 25, skor terendah (Min) 62, skor tertinggi (Max) 87 dan bahkan jumlah skor keseluruhan (Sum) sebesar 1424.

Deskripsi Motivasi Siswa Berjilbab

${ }_{18}$ Arfan Ikhsan, Metodologi Penelitian Akutansi Keperilakuan, (2008):248.

${ }^{19}$ Sujuko Efferin, dkk, Metode Penelitian Akutansi, (2008):197-199. 
Adapun variabel terikat (Y) adalah motivasi siswa berjilbab kelas VI, untuk variabel Y ada 14 item pernyataan. Pengukuran skor masing-masing item soal menggunakan skala Likert. Pernyataan angket setiap itemnya diberikan 5 buah alternatif jawaban. Responden yang menjawab (SS) menunjukkan sangat setuju, diberi nilai 5, pilihan (S) menunjukkan setuju diberi nilai 4, pilihan (KS) menunjukkan kurang setuju diberi nilai 3, pilihan (TS) menunjukkan tidak setuju diberi nilai 2, pilihan (STS) menunjukkan sangat tidak setuju diberi nilai 1.

Berdasarkan hasil deskriptif data responden dari skor hasil perhitungan angket variabel motivasi siswa berjilbab kelas VI dengan bantuan program SPSS versi 22.0, dari data 19 responden, diperoleh mulai dari rata-rata (mean) 56,58, titik tengah (Median) 55,00, nilai yang sering muncul (Mode) 51, simpangan baku (Standar deviasi) 6,611, tingkat penyebaran data (Variance) 43,702, rentangan (Range) 23, skor terendah (Min) 47, skor tertinggi (Max) 70 dan bahkan jumlah skor keseluruhan (Sum) sebesar 1075 sudah terlihat di tabel.

Analisis Regresi Linier Sederhana

Setelah melakukan normalitas, linearitas, heterodekastisitas, autokorelasi tentang pengaruh kepribadian guru pendidikan agama Islam dan motivasi siswa berjilbab, maka setelah itu akan dilakukan regresi linier sederhana dengan menggunakan aplikasi SPSS versi 22.0 Analisis regresi digunakan untuk mengetahui atau mengukur pengaruh antara variabel bebas terhadap variabel terikat. Adapun analisis regresi sederhana digunakan untuk memprediksi variabel terikat (Y) apabila variabel bebas $(\mathrm{X})$ telah diketahui. untuk mengetahui pengaruh kepribadian guru pendidikan agama Islam terhadap motivasi siswa berjilbab di SD Negeri 18 Sungaiselan, peneliti melakukan analisis regresi linier sederhana dengan menggunakan program SPSS 22.0.

Berdasarkan output tabel model summary diperoleh informasi bahwa angka R Square atau koefisien determinasi $\mathrm{R}^{2}=0,314$ X $100=31,4 \%$. Artinya, variasi pada variabel kepribadian guru pendidikan agama Islam sebesar 31,4 \% dan sisanya 68,6 \% dipengaruhi oleh faktor-faktor lain yang tidak dijadikan sebagai variabel independen.

Berdasarkan input tabel $A N O V A^{\mathrm{b}}$ dapat digunakan untuk menguji tingkat signifikasi regresi. Pedoman yang digunakan pada tabel ini dengan melihat kriteria berikut:

a. Jika nilai sig. $<0,05$ maka signifikan.

b. Jika nilai sig. $>0,05$ maka tidak signifikan.

Berdasarkan output tabel ANOVA ${ }^{\mathrm{b}}$ bahwa nilai sig. ,013. Dengan demikian nilai signifikansi lebih kecil dari $0,05(0,013<0,05)$, jadi dapat disimpulkan bahwa terdapat pengaruh yang signifikan antara kepribadian guru pendidikan agama Islam terhadap motivasi siswa berjilbab.

Pada output tabel Coefficients ${ }^{a}$ diperoleh nilai $\mathrm{T}_{\text {hitung }}$ 2,789 kemudian dalam menetapkan $\mathrm{T}_{\text {tabel }}$ dengan rumus $\mathrm{dk}=\mathrm{n}-\mathrm{k}$ yaitu $19-2=17$ responden sehingga diperolah $\mathrm{T}_{\text {tabel }}=1,739$.. Selanjutnya setelah kedua nilai $\mathrm{T}$ diketahui, selanjutnya membandingkan nilai $\mathrm{T}_{\text {hitung }}$ dengan $\mathrm{T}_{\text {tabel }}$ untuk menguji hipotesisnya. Adapun kriteria pengujiannya sebagai berikut:

a. Jika nilai $\mathrm{T}_{\text {hitung }}>\mathrm{T}_{\text {tabel }}$ maka signifikan $\left(\mathrm{H}_{\mathrm{o}}\right.$ ditolak)

b. Jika nilai $\mathrm{T}_{\text {hitung }}<\mathrm{T}_{\text {tabel }}$ maka tidak signifikan $\left(\mathrm{H}_{\mathrm{a}}\right.$ diterima)

Berikut hipotesis yang dinyatakan dalam bentuk kalimat:

$\mathrm{H}_{\mathrm{a}}$ : Terdapat pengaruh yang signifikan antara kepribadian guru pendidikan agama Islam dengan motivasi siswa berjilbab.

$\mathrm{H}_{\mathrm{o}}$ : Tidak terdapat pengaruh yang signifikan antara kepribadian guru pendidikan agama Islam dengan motivasi siswa berjilbab.

Berdasarkan data yang telah dipaparkan di atas, maka dapat disimpulkan bahwa $\mathrm{T}_{\text {hitung }}>\mathrm{T}_{\text {tabel }}$ dengan angka 2,789 >1,739, berarti $\mathrm{H}_{\mathrm{a}}$ diterima dan $\mathrm{H}_{\mathrm{o}}$ ditolak.

Untuk membuat persamaan Regresi Linier Sederhana, sesuai dengan rumus persamaan yang telah dipaparkan, yaitu dengan melihat tabel Coefficients ${ }^{a}$, kemudian didapat nilai untuk konstantanya sebesar 13,196 dan nilai koefisien b1 (kepribadian guru pendidikan agama Islam) sebesar 0,579. Berdasarkan angka yang diperoleh, maka bentuk persamaan regresi linier sederhana dapat dinyatakan sebagai berikut:

$\hat{\mathrm{Y}}=13,196+0,579 \mathrm{X}$

Dengan demikian dapat dilihat untuk koefisien regresi linier variabel kepribadian guru pendidikan agama Islam (X) bernilai positif, 13,196. Artinya terjadi hubungan positif antara kepribadian guru pendidikan agama Islam dengan motivasi siswa berjilbab. Sehingga dapat diprediksikan, jika kepribadian guru pendidikan agama Islam semakin baik, maka akan meningkatkan motivasi siswa berjilbab sebesar 0,579 atau sebaliknya.

B. Pembahasan Hasil Penelitian 
Berdasarkan teori kedua variabel dan hasil pengujian hipotesis yang telah diuraikan, maka terbukti bahwa pengaruh kepribadian guru pendidikan agama Islam berpengaruh signifikan terhadap motivasi siswa berjilbab. Adapun hasil analisis pengaruh kepribadian guru pendidikan agama Islam terhadap motivasi siswa berjilbab adalah sebagai berikut:

1. Perhitungan melalui koefisien regresi antara pengaruh kepribadian guru pendidikan agma Islam (X) terhadap motivasi siswa berjilbab (Y) adalah 0,579. Hal ini menunjukkan bahwa kepribadian guru pendidikan agama Islam terhadap motivasi siswa berjilbab berpengaruh cukup tinggi. Hal tersebut dibuktikan oleh tabel di bawah ini:

Tabel Interpretasi Koefisien

\begin{tabular}{|l|l|}
\hline $\begin{array}{c}\text { Interv } \\
\text { al } \\
\text { Koefis } \\
\text { ien }\end{array}$ & $\begin{array}{l}\text { Kekuata } \\
\mathrm{n}\end{array}$ \\
\hline 0,000 & korelasi \\
- & Sangat \\
0,199 & Rendah \\
\hline 0,200 & Rendah \\
- & \\
0,399 & \\
\hline 0,400 & Cukup \\
- & Tinggi \\
0,599 & \\
\hline 0,600 & Tinggi \\
- & \\
0,799 & \\
\hline 0,800 & Sangat \\
\hline- & Tinggi \\
\hline 1,000 & \\
\hline
\end{tabular}

2. Tingkat signifikasi koefisien regresi satu sisi (2-tailed) memperoleh nilai probabilitas 0,013. Dalam hal ini nilai probabilitas $0,013<0,05$ (5\% taraf signifikansi), maka regresi antara kepribadian guru pendidikan agama Islam terhadap motivasi siswa berjilbab dinyatakan signifikan. Angka R Square atau koefisien determinasi $\mathrm{R}^{2}=0,314$ X $100=31,4 \%$. Artinya, variasi pada variabel kepribadian guru pendidikan agama Islam sebesar 31,4\% dan sisanya 68,6\% dipengaruhi oleh faktor-faktor lain yang tidak dijadikan sebagai variabel variabel independen.

3. Setelah diuji sesuai dengan prosedur dan langkah-langkah proses perhitungan mulai dari instrumen sampai dengan proses regresi linier sederhana bahwa terdapat pengaruh yang cukup tinggi dari pengaruh kepribadian guru pendidikan agama Islam terhadap motivasi siswa berjilbab kelas VI SD Negeri 18 Sungaiselan Kabupaten Bangka Tengah.

Adapun hasil dalam penelitian ini terdapat persamaan regresi linear sederhana antara lain $\hat{Y}=$ $13,196+0,579 X$. Kemudian terlihat dari hasil perhitungan dengan analisis regresi linear sederhana untuk koefisien regresi X Kepribadian Guru Pendidikan Agama Islam sebesar 0,579 mempunyai tanda positif. Hal ini memberikan arti bahwa pentingnya variabel X dalam mempengaruhi variabel Y.

\section{KESIMPULAN}

Berdasarkan hasil penelitian dan pendekatan tentang pengaruh kepribadian guru pendidikan agama Islam terhadap motivasi siswa berjilbab kelas VI di SD Negeri 18 Sungaiselan Kabupaten Bangka Tengah, dapat disimpulkan :Besarnya pengaruh kepribadian guru pendidikan agama Islam terhadap motivasi siswa berjilbab antara lain: Dari hasil wawancara seorang siswa pada BAB 1 mengatakan bahwa salah satu motivasi meraka menggunakan jilbab adalah ketika mereka melihat guru-guru dan teman-teman mereka yang berjilbab. Selanjutnya diperkuat dengan data-data dari skor rata-rata (mean) kepribadian guru pendidikan agama Islam berjumlah 74,95 dan skor rata-rata (mean) motivasi siswa berjilbab berjumlah 56,58. Hasil persamaan regresi linier sederhana, yaitu: $\hat{Y}=$ $13,196+0,579 X$. Sehingga besar kontribusi variabel motivasi siswa berjilbab ditentukan oleh kepribadian guru pendidikan agama Islam yakni sebesar 31,4 \%, sedangkan 68,4\% ditentukan oleh faktor lain yang tidak diteliti dalam penelitian ini, ditambah lagi dengan nilai R Square sebesar 0,314. 
Dari hasil pembahasan di atas dapat menjelaskan bahwa kepribadian guru pendidikan agama Islam memiliki peran penting dalam mempengaruhi motivasi siswa berjilbab kelas VI di SD Negeri 18 Sungaiselan Kabupaten Bangka Tengah.

\section{REFERENSI}

Andang. 2014.Manajemen dan Kepemimpinan Kepala Sekolah. Yogyakarta: Ar-Ruzz Media.

Arifin, Zainal. 2012.Penelitian Pendidikan. Bandung: PT Remaja Rosdakarya.

Astriyandi, Ari, Umi Chotimah, dkk. 2016. Kemampuan Guru Menerapkan Penilaian Autentik dalam Pembelajaran PPkn. Jurnal Bhinneka Tunggal Ika, Volume 3, Nomor 2.

Basuki, Ismet dan Hariyanto. 2016.Asesmen Pembelajaran. Bandung; PT Remaja Rosdakarya.

Bungin, Burhan. 2013.Metodologi Penelitian Kuantitatif: Komunikasi Ekonomi Kebijakan Publik Serta Ilmu-Ilmu Sosial Lainnya. Jakarta:Kencana.

Darmadi, Hamid. 2011. Metode Penelitian Pendidikan. Bandung: Alfabeta.

Fathurrohman, Muhammad, dan Sulistyorini. 2012. Belajar dan Pembelajaran Membantu Meningkatkankan Mutu Pembelajaran sesuai Standar Nasional. Yogyakarta: Teras.

Fadlillah, M. 2014. Implementasi Kurikulum 2013 dalam Pembelajaran SD/MI, SMP/MTs, \& SMA/MA. Yogyakarta: AR-RUZZ Media.

Kurinasih, Imas dan Berlin Sani. 2014.Implementasi Kurikulum 2013 Konsep dan Penerapan. Surabaya: Kata Pena . 2016.Revisi Kurikulum 2013 Implementasi konsep dan penerapan. Surabaya: Kata Pena.

Kunandar. 2010. Guru Profesional Implementasi Kurikulum Tingkat Satuan Pendidikan (KTSP) dan Sukses dalam Sertifikasi Guru. Jakarta: Raja Grafindo Persada. 2015. Penilaian Autentik (penilaian hasil belajar peserta didik berdasarkan kurikulum 2013) suatu pendekatan praktis disertai dengan contoh. Jakarta: Raja Grafindo Persada.

N, Sudirman. 1990. Ilmu Pendidikan, (Bandung: Remaja Rosdakarya.

Permendikbud No. 69 Tahun 2013 tentang Kerangka Dasar dan Struktur Kurikulum Sekolah Menengah Atas / Madrasah Aliyah.

Riduwan. 2007. Skala Pengukur Variabel-Variabel Penelitian. Bandung: Alfabeta. 2009. Dasar-Dasar Statistika. Bandung: Alfabeta . 2013. Belajar Mudah Penelitian untuk Guru-Karyawan dan Peneliti Pemula. Bandung: Alfabeta.

Rifa'i, Veithzal. 2003.Upaya-Upaya Meningkatkan Hasil Belajar Kepemimpinan Peserta Diklat Spama Survei di Diklat Depkes. Jurnal Pendidikan dan Kebudayaan N0.40, tahun ke-9, jakarta: Depdiknas.

Rumengan, Jemmy. 2015. Aplikasi Statistik dalam Penelitian Kuantitatif. Bandung: Citapustaka Media. Sabri, Alisuf. 1996.Psikologi Pendidikan. Jakarta: Pedoman Ilmu Jaya.

Sudijono, Anas. 2015. Pengantar Statistik Pendidikan. Jakarta: PT Raja Grafindo Persada.

Sugihartono, dkk. 2007.Psikologi Pendidikan. Yogyakarta: UNY Press.

Sugiyono. 2014.Metode Penelitian Pendekatan Kuantitatif, Kualitatif, dan R\&D. Bandung: Alfabeta.

Sugiyono dan Eri Wibowo. 2004.Statistika untu Penelitian. Bandung: Alfabeta.

Supriyono. 1991.Perlu Motivasi Instrinsik yang Kuat untuk Meraih Prestasi Belajar. Jakarta:Media. 